\title{
THE LEGAL CONSTRUCTION MODEL FOR THE COLLUSION AND NEPOTISM OFFENSE TO BE OPTIMAL AS AN INSTRUMENT TO PREVENT CORRUPTION
}

\author{
Ali Mukartono ${ }^{1}$;Hartiwiningsih ${ }^{2}$; Muhammad Rustamaji ${ }^{3}$; Pujiyono ${ }^{4}$ \\ Ph.D Student at Faculty of Law Universitas Sebelas Maret \\ Professor of Business Law at Faculty of Law Universitas Sebelas Maret
}

\begin{abstract}
-
This paper aimed to elaborate the legal construction model for the collusion and nepotism offense to be optimal as an instrument to prevent corruption in Indonesia. Numerous efforts have been implemented by the government to prevent and thoroughly eradicate corruption, which is tagged a white-collar and extraordinary crime. During the reform period, several institutions were implemented to help in the eradication of corruption but corruption cases in Indonesia have been increasing significantly. This paper uses the normative legal research. proper legal construction model is needed in handling collusion and nepotism, which starts by making new laws directed towards the direction of the applied state to achieve its goals. The formation of a new law needs to cover enforcement agencies. Furthermore, Human Resources need to be reformed and intensified to develop people that understand the law, in order to determine the dangers of collusion and nepotism, thereby preventing corruption. Similarly, in the institutional viewpoint, collusion and nepotism need to be handled by the KPK, police, and the prosecutor's office in order

to

preventcorruption.
\end{abstract}

Keywords: Legal Construction; Corruption; Human Resources.

\section{A. Background}

Indonesia is currently angered by many corruption-related cases in the executive, legislative, judiciary, and private sectors. Therefore, eradicating corruption is one of the main focus of the Government and the people. Etymologically, corruption comes from the Latin word "corruptio" or "corruptus" and from the verb "corrumpere" which means rottenness, depravity, dishonesty, bribery, immorality, and deviation from purity. This word was further translated into several European languages. For instance, in England and France, it is known as "corruption," while in Dutch, it is called "korruptie." In the Big Indonesian Dictionary, it is called corruption and associated with the act of carrying out fraud or embezzlement by a state, nation, or company for personal or other people's gain. $^{1}$

Articles 1 number 4 and 5 of Law Number 28 of 1999 concerning State Administrators that are clean and free from corruption and nepotism

\footnotetext{
${ }^{1}$ http://kbbi.web.id/korupsi.
}

emphasize the definition of criminal activities. Collusion is an unlawful consensus or cooperation between State Administrators or parties, which create negative effects to the community, and the state. Nepotism is an act of State Administrators against the law which places the interests of their families and cronies above the community, nation, and state. Therefore, the widespread of collusion and nepotism is also a violation of the social and economic rights of the community, hence it is categorized as an extraordinary crime.

Numerous efforts have been implemented by the government to prevent and thoroughly eradicate corruption, which is tagged a white-collar and extraordinary crime. During the reform period, several institutions were implemented to help in the eradication of corruption, in addition to the Police and the Attorney General's Office. These institutions include the Corruption Eradication Commission (KPK), the Financial Transaction Reports and Analysis Center (PPATK), and the Witness and Victim Protection Agency (LPSK).Corruption is the 
act of deviating from society's social and legal norms, which are threatened with sanctions by the state. It is the abuse of position, power, and opportunity to fulfill the interests of oneself and their Group against common interests (society) ${ }^{2}$.

The corruption eradication process needs to be optimized to eliminate the widespread of corruption, which creates adverse effect to the society. Corruption is attributed to dishonest, rotten, and lecherous behavior related to finances. ${ }^{3}$ It also poses a serious threat to stability and security, which weakens democratic institutions, ethical values, justice, endangers sustainable development and weakens the rule of law. ${ }^{4}$

The application of criminal law instruments against crimes related to collusion and nepotism is aimed at preventing financial losses. Therefore, studies related to criminal acts of collusion and nepotism is useful in protecting the interests of the state and society as opposed to those on corruption.

The negative impact and destructiveness of the collusion and nepotism indicates that there are still problems associated with eradicating process in the legal system, such as the structure and culture of the law. Therefore, it is necessary to immediately form a legal construction model to prevent collusive acts of nepotism that lead to criminal acts of corruption.

\section{B. Research methods}

This is a juridical sociological (non-doctrinal) and qualitative research, which basically covers the

\footnotetext{
${ }^{2}$ RB. Soemanto, Sudarto, Sudarsana (2014), Pemahaman masyarakat tentang korupsi: Jurnal Yustisa

${ }^{3}$ Sudarto, Hukum dan Hukum Pidana, Bandung: Alumni, 1996, hlm. 115

${ }^{4}$ Preambule United Nations Convention Against Corruption, 2003
}

entire Indonesia legislation [Burhan Arshofa, Legal Research Methods, Rineka Cipta, Jakarta, 1996]. Furthermore, this research descriptively shows the problems regarding the legal construction model associated with collusion and nepotism. Secondary data were collected through literature studies.

\section{Research Results and Discussion}

\section{The legal construction model for the offense of collusion and nepotism as an optimal instrument for the prevention of corruption in Indonesia}

The actions related to collusion and nepotism are called mala banita, and mala in se. These actions lead to adverse effects, such as losses in financial industry. Collusion and nepotism destroy the friendly relationship among people, there causing conflict or disputes. Therefore, they are indeed very despicable and deserve to be declared as criminal acts.

The reprehensible analysis of these acts is carried out by searching (heuristics) the legal principles relevant to the nature of the ideas, such as the meanings and objectives. This is usually in the form of criminal law reasoning, which tends to depart from departs from momentum. ${ }^{5}$ Heuristics comes from the word 'heuriskein' which means 'to seek.' Therefore, the search process indicates that several criminal law principles act as the basis for theory, which aligns with the objectives of collusion and nepotism in accordance with the Heuristics principles.

This is in accordance with the Decree of The People's Consultative Assembly of the Republic of

5 Sidharta, 'Heurestika dan Hermeneutika : Penalaran Hukum Pidana', dalam Jufrina Rizal dan Suhariyono AR (editor), Demi Keadilan : Antologi Hukum Pidana dan Sistem Peradilan Pidana: enam dasawarsa Harkristuti Harkrisnowo, Pustaka Kemang, Jakarta, 2016, h.9-10. 
Indonesia (MPR) Number XI / MPR / 1998 dated November 13, 1998, on State Administrators that are clean and free of corruption, collusion, and nepotism. Furthermore, the Government in order to implement the MPR decision, issued Law Number 31 of 1999 concerning Eradication of Corruption in lieu of Law Number 3 of 1971 concerning Eradication of Corruption Crimes.

Furthermore, Law Number 28 of 1999 concerning the implementation of a country free and clean from corruption, collusion, and nepotism was issued. This is also in accordance with Article 2 Number 7 of MPR Decree Number VIII/MPR /2001, which stated that it is necessary to immediately formulate a law to prevent the occurrence of these criminal activities.

The MPR Decree Number VIII / MPR / 2001 implies that it is necessary to take action to prevent corruption. MPR Decree Number XI / MPR / 1998 concerning State Administrators that are clean and Free of Corruption, Collusion and Nepotism, is in accordance with MPR Decree Number VIII / MPR / 2001. This is also in line with Law Number 28 of 1999 concerning State Administrators, which have been implemented in their respective policies.

Therefore, the criminal act of corruption is an extraordinary crime that needs outstanding methods to carry out the handling processes. The legal process is one of the right choices in solving corruption related-cases as a manifestation of the rule of law mandated by the constitution. This matter shows the emergence of several indications that enhances the law enforcement efforts.

The major disadvantage of corruption is loss of finances. The issuance of the Constitutional Court Decision Number 25/PUU-XIV/2016, used the phrase "can" in Articles 2 and 3 of Law Number 31 of 1999 to determine the Corruption Crimes Eradication, process after the loss of state finances. This method is not a guaranteed successful recovery process because it needs more time and money.

Therefore, based on this, there is a need to carry out legal reform on corruption eradication using the political-law approach, which is basically a direction enforced by the state to achieve its goals by replacing old laws with new ones. The legal-political urgency used to make statutory regulations is associated with statutory regulation and the ability to determine the factors that need to be translated into legal sentences. These two attributes are important because statutory regulations and the research formulation are a "bridge" between the established legal politics and implementing the legislation. ${ }^{6}$

In Law Number 31 of 1999 as amended by Law Number 20 of 2001 concerning the Corruption Crimes Eradication, there are at least 8 (eight) groups of corruption offenses, namely:

a. Offense groups that harm the state's finances or the country's economy,

b. The bribery offense group (active or passive),

c. The embezzlement offenses Group in office,

d. The extortion offenses group in office (knevelarij, extortion),

e. Falsification offenses group,

f. The offense group deals with chartering, suppliers, and partners,

g. Gratification offense group,

h. Offense groups that obstruct the corruption handling cases.

Furthermore, based on the 2003 United Nations Convention Against Corruption (UNCAC),

${ }^{6}$ Moh. Mahfud M.D., Membangun Politik Hukum, Menegakkan Konstitusi, PT Raja Grafindo Persada, Jakarta, 2010, pg.5. 
which was ratified by Indonesia through Law Number 7 of 2006 concerning Ratification of the United Nations Convention Against Corruption, 2003, the corruption scope covers the following:
a. Bribery of national public,
b. Bribery of foreign public official and officials of a public international organization,
c. Embezzlement, misappropriation, or other transfer of assets by a public official (trading in influence),
d. Abuse of functions,
e. Illicit enrichment,
f. Bribery in the private sector,
g. Embezzlement of property in the private sector.

The bureaucratic reform program is associated with the human resources (HR) aspect, which implements policies to drive all bureaucratic reform programs. ${ }^{7}$ However, building the state apparatus's integrity and ethics is not only briefly carried out through a mere bureaucratic reform program. Therefore, discussions on law enforcement are always related to the legal system elements, namely the substance, structure, and legal culture (society).

In analyzing corruption eradication problems in Indonesia, Elwi Danil stated that it is associated with the legal culture aspects that have not been developed and appropriately fostered. Therefore, adequate attention needs to be paid to develop a legal culture using appropriate law enforcement strategies ${ }^{8}$

The state apparatus's integrity and ethics development need to be carried out simultaneously in

\footnotetext{
${ }^{7}$ Bambang Waluyo, 2014, optimalisasi pemberantasan korupsi di Indonesia : Jurnal Yuridis

${ }^{8}$ Elwi Danil, Korupsi : Konsep, Tindak Pidana dan Pemberantasannya, (RajaGrafindo Persada, Jakarta, 2014), hal. 272.
}

all industries, especially schools. Therefore, a reorientation of the formal education curriculum and service need to be incorporated with the noble values of the Indonesian people, such as those originating from religion, culture, and national ideology, namely Pancasila. These noble values need to be actualized to ensure efforts to build integrity and ethics of the state apparatus are realized in daily life. State apparatus with integrity and ethics is one of the requirements for the realization of good governance, clean and free from Corruption, Collusion, and Nepotism.

Based on an institutional viewpoint, the existence of Indonesian Corruption Eradication Commission (KPK) law enforcement as an agency to eradicate corruption, both from the prevention and prosecution side, is an important requirement needed to create an Indonesia that is free from corruption crimes. However, amidst high levels of corruption, investigators and public prosecutors' availability has not been matched. This obstacle ultimately makes corruption eradication performance to run slowly. For instance, the availability of investigators and public prosecutors at KPK is limited. On the other hand, law enforcement agencies focus on handling the problems without paying attention to collusion and nepotism.

Corruption continuously occurs as long as the eradication process is still sectoral and institutional egocentrism remains high between the police, the Attorney General's Office, and the KPK. The fragmentation of anti-corruption investigation institutions creates a tendency for agency centrism or fragmentation. Therefore, it affects the case handling process from the police investigators to Public Prosecutors. Furthermore, the absence of integrity and harmony related to ideas, values, norms, and regulations that form the basis of the professional code of ethics makes the output inconsistent with the 
investigations, thereby leading to corruption and criminal activities.

Hibnu Nugroho ${ }^{9}$ stated that the existing corruption investigation institutions in Indonesia, namely police, prosecutors, and KPK investigators, are regulated by a separate law. For instance, the Police investigators, Attorney General's Office, and KPK investigators that have separate rules or norms and are prone to create ego sectoral and excessive love for their institutions, thereby leading to the investigators' independence and objectivity in handling cases related to their institution.

The establishments of an integrated regulation among laws are beneficial to many groups ${ }^{10}$. It also strengthens public trust in law enforcement officials. On the other hand, the presence of inconsistency in law enforcement is judged by the public, thereby weakening their trust, legal culture, and compliance. Therefore, corruption needs to be eradicated in various institutions. Furthermore, a structure is needed, which recommends harmonizing legal institutions, such as the KPK, the police, and the Attorney General's Office. This is because the KPK is assisted by the Police and the Attorney General's Office to eradicate collusion and nepotism to prevent corruption. Therefore, it is important to maintain the integrity and synergy of these three institutions.

\section{Conclusion}

In conclusion, proper legal construction model is needed in handling collusion and nepotism, which starts by making new laws directed towards the direction of the applied state to achieve its goals. The

\footnotetext{
${ }^{9}$ Hibnu Nugroho, Membangun Model Alternatif Untuk Integralisasi Penyidik Tindak Pidana Korupsi di Indonesia, (Semarang: Dissertation of Doctoral Program in Law, Diponegoro University, Semarang, 2011) pg 75

${ }^{10}$ http://pji.kejaksaan.go.id/
}

formation of a new law needs to cover enforcement agencies. Furthermore, Human Resources need to be reformed and intensified to develop people that understand the law, in order to determine the dangers of collusion and nepotism, thereby preventing corruption. Similarly, in the institutional viewpoint, collusion and nepotism need to be handled by the $\mathrm{KPK}$, police, and the prosecutor's office in order to prevent corruption.

\section{E. Recommendation}

A new legal construction model needs to be created to accommodate and regulate collusion and nepotism. Furthermore, there need to be laws that deeply examine criminal activates related to collusion and nepotism. The integrity and ethics of the state apparatus need to be carried out simultaneously.

\section{F. References}

1. Bambang Waluyo, 2014, optimalisasi pemberantasan korupsi di Indonesia : Jurnal Yuridis

2. Burhan Arshofa, Metode Penelitian Hukum, Rineka Cipta, Jakarta, 1996,

3. Elwi Danil, Korupsi : Konsep, Tindak Pidana dan Pemberantasannya, (RajaGrafindo Persada, Jakarta, 2014)

4. Hibnu Nugroho, Membangun Model Alternatif Untuk Integralisasi Penyidik Tindak Pidana Korupsi di Indonesia, (Semarang: Disertasi Program Doktor Ilmu Hukum Universitas Diponegoro Semarang, 2011)

5. Moh. Mahfud M.D., Membangun Politik Hukum, Menegakkan Konstitusi, PT Raja Grafindo Persada, Jakarta, 2010

6. Preambule United Nations Convention Against Corruption, 2003 
7. Sidharta, 'Heurestika dan Hermeneutika : Penalaran Hukum Pidana`, dalam Jufrina Rizal dan Suhariyono AR (editor), Demi Keadilan : Antologi Hukum Pidana dan Sistem Peradilan Pidana: enam dasawarsa Harkristuti Harkrisnowo, Pustaka Kemang, Jakarta, 2016

8. Sudarto, Hukum dan Hukum Pidana, Bandung: Alumni, 1996

9. RB. Soemanto, Sudarto, Sudarsana (2014), Pemahaman masyarakat tentang korupsi: Jurnal Yustisa

10. http://pji.kejaksaan.go.id/

11. http://kbbi.web.id/korupsi. 